\title{
WHAT IS A PROBLEM?
}

\section{ANDREW HAAS}

PhD, Associate Professor, National Research University - Higher School of Economics, 105066 Moscow, Russia.

E-mail: ahaas@hse.ru

What is a problem? What is problematic about any problem whatsoever, philosophical or otherwise? As the origin of assertion and apodeiction, the problematic suspends the categories of necessity and contingency, possibility and impossibility. And it is this suspension that is the essence of the problem, which is why it is so suspenseful. But then, how is the problem problematic? Only if what is suspended neither comes to presence, nor simply goes out into absence, that is, if the suspension continues, which continues the problem. But what is problematic about suspension? As a consideration of language shows, the problem of suspension is the problem of implication. If being, for example, is merely implied, neither present nor absent, then it is the suspension of both, at least insofar as it is problematic. And this not only says something about language; rather, it has ontological implications as well - it speaks of being, and the being of anything whatsoever. For if being is implied, if that is the problem of being, it is because being is an implication. Then the being of things like problems is implied as well; or being is in things by implication. But what does it mean for being to be neither presence nor absence, but an implication? It means that being is implied in a way that is problematic — before it is necessary, or even possible. For being's way of being is characterized by suspension - which has implications for thinking and speaking about being, and about things like problems, even about anything whatsoever. And this has implications for what being implies, namely, unity and time and aspect.

Key words: Apodeictic, aspect, assertoric, being, implication, problematic, suspension, time, unity.

\section{В ЧЕМ ЖЕ ПРОБЛЕМА?}

\section{ЭНДРЮ ХААС}

Доктор философии, профессор, Национальный Исследовательский Университет - Высшая Школа Экономики, 105066 Москва, Россия.

E-mail: ahaas@hse.ru

В чем же проблема? В чем состоит проблематичность проблемы, не важно, философской или любой другой? Проблематичность как источник утверждения и аподиктического суждения подвешивает такие категории, как необходимость и случайность, возможность и невозможность. И именно эта подвешенность является сущностью проблемы, в силу чего проблема вообще

(C) Andrew HaAs, 2015 
оказывается подвешиваемой. Но тогда насколько проблема проблематична? Настолько, насколько то, что подвешено, не проясняется и не исчезает, т. е. насколько подвешивание длится, продлевая тем самым проблему. Но что составляет проблематичность подвешивания? Как показывают размышления о языке, проблема подвешивания - это проблема импликации. Например, если бытие просто подразумевается, не будучи присутствующим или отсутствующим, тогда мы имеем дело с подвешиванием как присутствия, так и отсутствия, по крайней мере, пока эта альтернатива является проблематичной. И это говорит кое-что не только о языке; более того, это также имеет онтологические импликации в той мере, в какой речь идет о бытии вообще и о бытии чего угодно. Поскольку если бытие подразумевается, если в этом состоит проблема бытия, то это так, потому что бытие есть нечто подразумеваемое. Но что значит для бытия: не быть ни присутствием, ни отсутствием, но быть имплицитно данным? Это значит, что бытие дано в качестве проблематичного прежде, чем оно оказывается необходимым, или даже возможным. Ведь бытие характеризуется подвешиванием, которое имеет следствия для мышления и разговора о бытии, вопросах и проблемах, касающихся чего угодно. Это также влияет на то, что подразумевает бытие, а именно, на единство, время и выражение.

Ключевые слова: Аподиктический, выражение, ассерторический, бытие, импликация, проблематическое, подвешивание, время, единство.

What is a problem? The question is three-fold. It asks about the what of a problem, not just a philosophical problem, but any problem whatsoever; about the problem, about what is problematic about the problem; about the is of a problem, its being, that is, the being of the problem, and what is implied thereby.

\section{THE PROBLEMATIC OF THE PROBLEM}

There are, as Kant reminds us, two kinds of problems: conceptual problems, the easy, or easier, ones - which are not really problematic, but are non-problematic problems; and metaphysical problems, the tough ones - at least insofar as they cause problems, remain problematic. Conceptual problems are a question of knowledge, of the understanding of objects; metaphysical problems are a matter for thought, for reason. For there are things we cannot know and «yet must be able to think» — and that is the problem. $^{1}$

So, how can we think a problem without knowing it, without rendering it a nonproblem, without translating it into the language and logic of that which is no problem at all? In other words, what is actually problematic about the problem, about any problem whatsoever? And how can it be thought?

On the one hand, the conceptually or categorically problematic is neither assertoric nor apodeictic. ${ }^{2}$ This is in the Critique of Pure Reason, the Table of Judgments,

\footnotetext{
1 (Kant, 1900, III: B xxvi), my emphasis; see also: (Kant, 1900, III: B19, IV: 276, II: 83, 197).

2 (Kant, 1900, IV: A70-76/III: B 96-101, VIII: 193-194); see also: (Kant, 1900, IV: 414-415, IX:108).
} 
the Logical Function of the Understanding in Judgments, which is the Clue to the Discovery of All Pure Concepts of the Understanding. Judgments are a question of quantity, quality, relation or modality. And when it comes to modal judgment: «...we first judge something problematically, then take its truth assertorically, and finally claim it as inseparably united with understanding, that is, as necessary and apodeictic» (Kant, 1900, IV: A76/III: B101). Indeed, the problem is out of which the assertion comes, and which ends in the apodeiction. So the differences in these three modes of judgment, antecedens et consequens, are categorically clear. In apodeictic judgments, affirmation or negation is viewed as necessary, notwendig; or unnecessary, zufällig, contingent, if the judgement is not a priori determined, bestimmt, by the laws of the understanding. In assertoric judgments, affirmation or negation is real, true, an assertion of existence, of actually being there, of that which is the case, of what is wirklich, the presence of what is present; or unreal, untrue, false, fiction, like a waxworks figure, if the judgment asserts that which is not, not the case, not really being there or true, being not actually the case, unwirklich, so not present, but absent, not bound or verbunden to the laws of the understanding. In problematic judgements, affirmation or negation is taken to be possible, möglich; or its

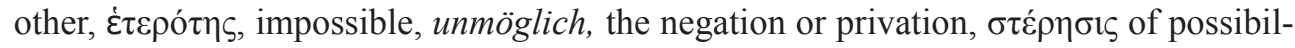
ity - at least insofar as the judgment is admitted, aufgenommen, by the understanding (Kant, 1900, II: 171).

Problematic knowledge then, is not a problem - for it is simply a question of knowing, subsuming in accordance with the law of non-contradiction, determining whether a judgment is possible or not. So while we must apodeict analytically from «all bodies are extended», to «this body is extended», or synthetically that 12 necessarily follows from 7+5; and we can assert that the Earth actually revolves around the Sun; we may only claim to know that vollkommene Gerechtigkeit, perfect or complete justice, is a possibility — for it can neither be determined as necessary a priori, nor shown to be actually present in the world, as Hegel might claim. ${ }^{3}$ For example, although nothing speaks for the impossibility of a perfectly just world, we must admit that it may turn out to be imperfect, even unjust. And if justice is not just ideal, but has its essence in the real world, and has not yet come to presence, insofar as history remains open, perhaps infinite; then we should probably not be surprised that the existence of perfect justice continues to be a question, a possibility of perfect justice, thus a perfection that is neither necessary nor actual.

On the other hand, there is another kind of problem, the metaphysically problematic - for knowledge of the conceptually problematic cannot be stretched to cover the entire sphere, Gebiet, of the problem. ${ }^{4}$ So we must necessarily think that which exceeds all understanding, empirical or transcendental, that of which we can have no intuition or

\footnotetext{
3 (Hegel, 1970, 24); (Kant, 1900, IV: A75/III: B100, IV:A 347/III:B 405).

${ }^{4}$ (Kant, 1900, IV: A255/III: B 310, X:132, 144, 266, II: 283).
} 
representation or concept, which is not categorically intelligible. And we must find a language to speak about that which goes beyond all conceptual discourse - but without simply translating or twisting the problematic problem into the unproblematic. For such a sophistical subterfuge, however normal nowadays, merely seeks to avoid a difficult question, to escape the tough problem by changing its meaning to suit our own abilities (Kant, 1900, IV: A 257/III: B 313). Rather, if the conceptually problematic is determined (in knowing and speaking) by the categories of the possible and the impossible, then we must seek to think a third, das Dritte. So Kant insists: the metaphysically problematic is that about which «we can neither say that it is possible nor that it is impossible» (Kant, 1900, IV: A287/III: B 343). Indeed, possibility and impossibility are categories that do not apply to the thinking and speaking of problems qua problematic. We may think, for example, the idea of soul, world, or God as thought-entities or thought-things, Gedankendinge; but we can neither reduce them to concrete substances nor transcendental concepts, neither to objects of the understanding nor to presentations or representations, neither to objects of possible experience nor to that which could not possibly be in anyway whatsoever, like some kind of impossible object or concept..$^{5}$ And if «the division into the possible and the impossible» is «the highest concept with which it is normal to begin a transcendental-philosophy» - well then, we will presumably have to go beyond the norm, to relinquish the usual subterfuge, die gewöhnliche Ausflucht, to give up the philosophy of the possible and the impossible, whether it dominates the present age, whether it seems to determine our words and deeds, thoughts and things, or not. For the problematic - the metaphysically problematic, that which is truly problematic, the tough problem or problematic problem - this resists the translations and transpositions, the permutations and combinations, the destructions and deconstructions, of the history of philosophy as the metaphysics of possibility (and impossibility); even if that means getting along without determining whether the problem is or is not, is necessarily or possibly, is «something or nothing», Etwas oder Nichts, that is, whether there is any problem whatsoever (Kant, 1900, IV:A 290/III: B 346).

If the problem of the problem then, is neither a question of the possible nor the impossible, is it merely a limit concept, a horizon of thought and word, so an empty object without concept, nihil negativum? In other words, is the problem something about which we cannot speak - and so must «remain silent» (Wittgenstein, 1921, §7)? Or is there a third thing, das Dritte - so tertium dator - a way of thinking that which is neither something nor nothing? And so suspends the philosophy of possibility and impossibility alike?

Indeed, the suspension of the problem is the suspension of the problem - for it is precisely this suspending (of apodeiction and assertion, something and nothing, the necessary and the unnecessary, the possible and the impossible) that points the way to the

5 (Kant, 1900, IV: A 335/III:B 392, IV:A 771/III:B 799). 
problem, to a philosophy of the problem, or a problematic philosophy. And this is what appears in Husserl under the name: غं the essence of the problem, which is probably why the experience of the problematic is so suspenseful.

So, what does it mean to suspend the possibility and impossibility of the prob-

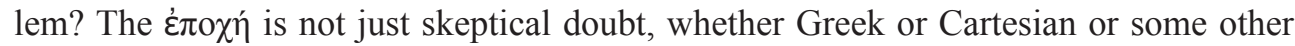
form; nor merely a question of necessarily abstaining or excluding, white-washing or washing-away, nor simply altering or changing from one possibility to another, nor just retreating to the assertion of impossibility, nor to both the possible and the impossible; much less assuming or presuming, supposing or presupposing, determining or judging (necessity or contingency), negating or destroying, destructuring or deconstructing rather, it is a way of holding, of keeping and keeping oneself back, of continuously holding back from judgment, Urteilsenthaltung (Husserl, 1977a, §§31-32). As a way

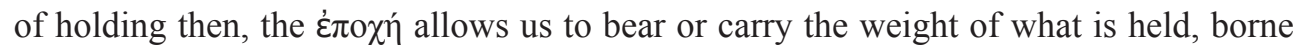

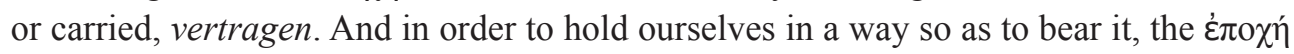
suspends judgment — including, for example, the natural attitude, consciousness, the natural and human sciences, prejudices and prejudicial significations, self-contradictory interpretations, the transcendent, the unity of mind and body, «Man», everything that «presents itself to me as factually existing» actuality (Husserl, 1977a, §§30, 88), that which seems to be actually and really there or not there, but elsewhere, as well as the categories of judgment and conceptual knowledge (necessity and contingency, existence and non-existence, possibility and impossibility). For in order to uncover the problem (even that which is problematic about things such as the absolute givenness of essences, transcendental consciousness, phenomena, intentional objects, cogitatum qua cogita-

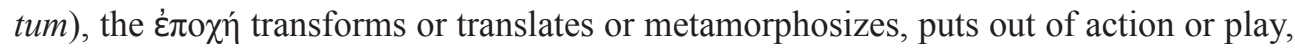
shuts or closes off, contains or parenthesizes; but not only negatively - for parenthesizing a judgment simpliciter holds onto it as a «parenthesized judgement»; and «the sus-

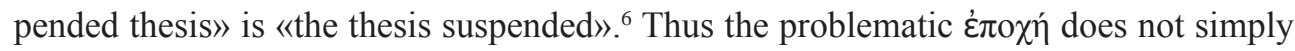
produce some kind of residuum, like pure subjectivity or transcendental ego, essence or

${ }^{6}$ (Husserl, 1973, 60); (Husserl, 1977a, §31). For Husserl as a philosopher of possibility, see: (Heidegger, 1977, 38). For an examination of Husserl's loyalty to the philosophy of presence, see: (Derrida, 1967, $73,92,96,115)$. For a reflection on human beings as suspended, see Kafka's landsman in «Before the Law», or Zarathustra's comment: «Man is a rope, tied between beast and overman - a rope over an abyss. A dangerous crossing, a dangerous on-the-way, a dangerous looking-back, a dangerous shuddering and stopping. What is great in man is that he is a bridge and not an end: what can be loved in man is that he is a going-over and a going-under» (Nietzsche, 1967, Part I, §4). For a consideration

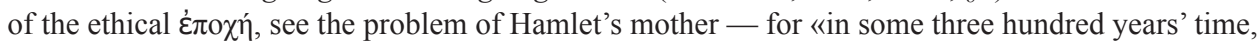
no consensus has been reached on this issue» of her guilt or innocence, complicity or participation; rather, it is suspended insofar as Shakespeare places «the question of the [presence of the] mother's guilt, or absence of it, between brackets» (Schmitt, 2006, 14-15). 


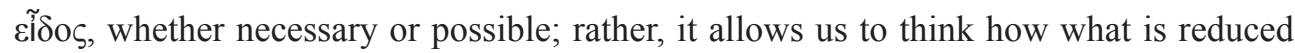
continues to be a problem (and the continuation of suspense, of what is suspended and the suspending itself — loss is a gain; putting out of play keeps in play; that which is in brackets remains bracketed; being suspended is being suspended).

And so too with the problem itself. Holding back from necessity and contingency, possibility and impossibility, something and nothing, suspending the usual subterfuge of the concepts by means of which we normally know and judge — this is the problem (and the way to think what is problematic about the problem, any problem whatsoever, if it is problematic). For suspension is that which suspends knowledge, and the necessary conditions of the possibility of knowledge - and the entire history of philosophy as a philosophy of the necessary or the possible, or its other, the contingent and the impossible - while continuing it qua problematic. But then the suspension of the problematic is just as much a problematic suspension; and not only knowing, but thinking too becomes problematic, even an exercise in making problems, that is, in suspending. And we may no longer be able to determine that there is necessarily a problem here, or there, or none at all, or that there may possibly be one, or must necessarily be one, or cannot be one, or that it is impossible to say that there is one - for all this unsuspends or deparenthesizes that which is problematic about the problem.

So what does it mean for the problem to be suspended? Or for thinking? And how can we think that which such a problematization renders problematic? For what does it mean «to be a problem»? In other words, what is the being of the problem?

\section{THE BEING OF THE PROBLEM}

Indeed, the question of the being of the problem implies the question of being itself. And this problem is the Platonic problem which leads Kant to «the central problem which has to be posed in the task of laying the foundation of a science of beings in general», which leads Heidegger to pose the problem that «underlying all beings are the principles of their being», which leads us to the problem of the being of the problem (Heidegger, 1977b, 46; my emphasis). ${ }^{7}$ So what is the being of the problem? What is being? And is this a problem? And if so, how so?

In fact, as Heidegger argues, since the Greeks, being has been understood neither as a particular being, nor as a genus (Aristotle, 1957, 998b), nor as a real predicate

\footnotetext{
${ }^{7}$ Heidegger raises «the question of the problem» in Kant and the Problem of Metaphysics, 1929 (Heidegger, 1991), two years after Being and Time, a text which remains within «the horizon of the Kantian problem» (Heidegger, 1977a, 31) — not just because it stays loyal to a philosophy of possibility (and impossibility - which may very well constitute the essence of transcendental philosophy as a whole), but because it follows Kant («the first and only» one to connect the problem of being with the problem of time) in forgetting about unity and aspect (Heidegger, 1977a, 23); see also: (Heidegger, 1991, xvi, xvii, 1; Heidegger, 1975, 36-107; Heidegger, 1984, 97).
} 
(Kant, 1900, IV: A 598/III: B 626) - for they do «not suffice to name everything that "is"» (Heidegger, 1983, 155) - but rather as presence (Heidegger, 1983, 46). In this way, coming into being, into existence or reality, appearing and showing, emerging and growing, means coming into presence out of absence, and so going out into absence; just as standing and staying, resting and remaining - throughout change and movement, identity throughout difference - means being continuously present, coming out of discontinuity. And whatever name the history of philosophy (or the history of philosophy as metaphysics, the study of being qua being, $\tau$ ò ôv ñ ôv) gives to being, to «everything that is», whatever determination comes to dominance, whether $\varphi v ́ \sigma 1 \varsigma$, number, matter, $\lambda$ ó $\gamma \circ$,

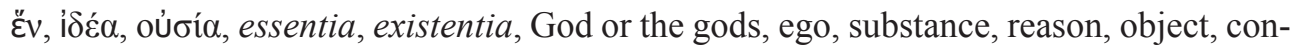
cept, spirit, will, power, etc. — it remains true to presence:

a definite, unitary trait runs through them all. It points our understanding of «to be» toward a definite horizon by which the understanding is fulfilled. The boundary drawn around the sense of «being» stays within the sphere of presentness and presence. ${ }^{8}$

So being is presence - for «from the dawn of Western-European thinking until today, being means the same as presencing» (Heidegger, 2007, 6).

But what is presence? It is not just a what, but a how - that is, how something is, how it presents itself, appears, shows itself, how it shines forth as what it is, the paivó $\mu \varepsilon v o v$, and the kind of being that it is; it is the way beings are, and thus, how problems, insofar as they are, are as well..$^{9}$ For being is itself not a being, although it is «always the being of a being», and so cannot be traced back to another, more original being; rather, being is the way any being whatsoever comes to presence. So if we say, for example, «the celebration took place in the presence of many guests», we mean that it took place «with many guests being present» — for here, being means present, letting be present, allowing to come to presence, revealing the presence of that which is present, unconcealing the event of being present, of being there (Heidegger, 2007, 14). And absence is merely its other, another, negative, privative, deficient way of being present, the event of non-being, non-presence - like an abyss that is there insofar as it is not there, or a Abgrund that still serves as a «Grund» (Heidegger, 1993, 48). Indeed, as

[the] being present of something $<\ldots>$ absence is constitutive for this presence, absence in the sense of deficiency, lack. This being-there in the sense of lack is completely its

${ }^{8}$ (Heidegger, 1983, 69); see: (Heidegger, 2007, 11; Heidegger, 1977a, 25; Heidegger, 1989, 193). On presence as a metaphysical problem, even the problem of ontology, onto-theology, or ontohenology - or more precisely, metaphysics qua onto-heno-chrono-phenomenology, see: (Haas, 2007a, 196).

9 (Heidegger, 1977a, 6, 27; Heidegger, 1985a, 50). 
own and positive. If I say of someone: «I miss him very much, he is not there», I precisely do not mean to say that he is not there, but express a quite particular way that he is there for $m e .^{10}$

Thus absence is a modality of presence, a way of presenting as non-presenting, present deprived of presence, or present by being absent - for being present and being absent are how being is, at least insofar as being is understood within the sphere of presentness, which is why presence is what being is.

So, for example, a natural thing - just as much as a cultural one - is present or absent in nature; and nature as a whole is this coming into presence and going out into absence; it is how trees and forests, plants, animals and humans, come to life, produce and reproduce, appear and unfold themselves in words and deeds, as thoughts and things, here and now, repeatedly, continuously, and then go there, out of presence into absence or death, once and for all, or again and again. For the being of nature, and natural things, is the presencing and absencing of what is. Thus, natural beings are present and absent - whether as a stone or animal, earth or world, once or forever, us or a god, mortal or immortal, real or ideal, in motion or at rest, potential or actual, necessary or contingent, possible or impossible - in accordance with different ways of presencing and absencing, that is, being.

But what does it mean to think being qua presence, or rather presence and absence? In fact, it means thinking being in relation to time - for being present (and/or absent) means being in time, happening at this time or that, simultaneously or not; or more precisely, insofar as «in» or «inness» is misleading, it means being temporally. And what is this time to which being is related? It is neither what we see on watches nor a measure of motion (Aristotle, 1950, 219b2), neither the order of things nor their schema (Kant, 1900, A142-143/B182); rather, time is a how, that is, how something comes to be, to presence, and so to be present (Heidegger, 2004, 124) - which is why ontology is essentially onto-chronology, and «the history of the concept of time...is the history of the

\footnotetext{
${ }^{10}$ (Heidegger, 2002, 311); see also: (Heidegger, 2007, 17-18). This privileging of presence motivates the deconstruction of the philosophy of presence: on the one hand, analogous to Augustine's analysis of time, absence is only thought on the basis of presence, which clarifies how that which is not present can still be - by being-absent; on the other hand, the possibility of absence, non-being, nothingness, non-presence (as well as the non-now, past and future, the non-possible or impossibility, the non-self or other, heterogeneity, difference, etc.), is undercut, translated or transmuted into presence-and there is no absence, merely a modification of presence; or absence is simply presence, a yet more devious means for maintaining the privilege of presence (Derrida, 1972, 33-34). For a discussion of a political philosophy of the possible and the impossible, see for example: (Derrida, 2001, 75-77; Derrida, 2003, 122-123). On the event of the abyss of being (or beyng), see for example: (Heidegger, 1989, 30, 371-388); (Haas, 2007b, 88-90). For a consideration of the ambiguity of being in Heidegger (presence/absence, event/non-event, Ereignis/Enteignis), see: (Haas, 2015b).
} 
question of the being of beings». ${ }^{11}$ In other words, time is the character of beings - not simply zeitlich, but temporal - and being implies time. Thus the meaning of being can only be illuminated in relation to temporality, which is why «time is the horizon for any understanding of being whatsoever». ${ }^{12}$

But if being qua presence is temporal - well then, what does that mean for beings which come to be in time? Language gives us a clue - for presence, present time, is a tense. This is why problems - and in fact, any word or deed, thought or thing - appear as tensed: we say that we have a problem in present tense; or that he had a problem in past tense; or that she will have a problem in future tense - although by «having», we mean «being»; a problem is present, it belongs to us, or we happen to have it with another. Or if we claim a problem comes from something, or has ramifications for someone, or if they have succumb to their problem, or if there is a problem, or no problem then we mean that there is an event in which it comes to presence and presents itself, whether it requires a response or not. Or if we are told that we are no longer «a problem child», we know the problem, which was present in our behavior, which showed itself in this act or that, is now absent, that is, present as having been overcome. For tense is a determination of verbs, which is why they are called Zeitwörte, time-words, in German. And if conjugation discloses action, how the deed is done, the way in which events occur - whether eating or drinking, sensing and imagining, knowing and understanding, speaking or thinking, doing or making, having or being - it is because all verbs take time; or more precisely, because language is not just in time, but is temporal.

Then, so too with problems: if presence is understood as the way something is, then it is how something is problematic (1) in the present, being there now; or (2) was in the past, and so is present qua having been, whether in memory or retention; or (3) will be in the future, and so present qua to be, whether in protention or anticipation (even if different times, implying one another, are what let problems be how they are, were and will be, just as being is what lets time come into presence and go out into absence). So no problem of time without being and no being problematic without time, which is why the presence and absence of being has the temporality of the present or non-present (past or future). In other words, a problem is one, or becomes one, only insofar as it is present or comes to presence, presents itself in one way or another. Thus, a problem is an actual problem, or is a possible one, a problem that is problematic for me or you, us or them, here or there, now or then, a problem that is one of words or deeds, thoughts or things, one that is real or imaginary, a problem that is conceptual or metaphysical, that presents itself as necessarily or possibly, actually or potentially, solvable or insolvable all these ways of being a problem, of being problematic, are ways in which problems are present now or not now, how they come to presence and present themselves, or present

\footnotetext{
${ }^{11}$ (Heidegger, 1979, 191); see: (Heidegger, 2002, 313, 379); (Heidegger, 1976, §15); (Haas, 2015a).

12 (Heidegger, 1977a), «Front-piece»; see: (Heidegger, 1977a, 25); (Heidegger, 1975, 435).
} 
themselves as non-problems, no longer problematic, solved or resolved, possibly even old and tired, having been superseded or overcome, and so absent.

And yet, if the being of a problem is its presence, how it is present (or absent), which implies that it has its tense, its time - then it also has its aspect. For time alone cannot account for the ways of being of a problem, nor for how being is. Another clue from language: all verbs, like being, have tense (past-present-future, now and not-now, present and non-present) and aspect (simple-continuous-completed, complete and incomplete) - which is neither mood (indicative-subjunctive-optative), nor voice (active-middle-passive); and certainly nothing like perspective or view, side or face. ${ }^{13}$ Rather, aspect is the other of time; it is the way in which anything whatsoever is at each and every time, and at any time whatsoever. Aspect is the other how of deeds done, of everything that is. So at one and the same time, I can think (discontinuously-completely) and be thinking (continuously-incompletely) about a problem, even one like perfect justice - in present time, or with the temporality of what is present; I might have thought and have been thinking about it; or I shall think and shall have thought it. And the difference between these ways of being, of being a problem, whether conceptually or metaphysically, is an aspectual difference. But then every temporal problem is an aspectual one as well; or any time a problem happens to come to presence, presents or absences itself, it does so with aspect - for being, and being a problem, or being problematic, has a double-character, temporal-aspectual, at least insofar as aspect is the other of time. ${ }^{14}$

But not just time - for being too has its other. As Aristotle reminds us:

Now, if being and unity are the same and are of one nature in the sense that they are implied by one another as principle and cause, but not in the sense that they have the same definition $<\ldots>$ for «one man» and «man» are the same thing, and so are «being man» and «man» and the doubling of the words in «one man and being one man» does not express anything different; it is clear that the two things are not separated either in coming to be or in ceasing to be $\langle\ldots>$ so that it is obvious that the addition in these cases means the same thing, and unity is nothing apart from being... - all this being so, there must be exactly as many kinds of being as of unity (Aristotle, 1957, 1003b 22-34).

\footnotetext{
${ }^{13}$ (Haas, 2015a). Modality is not aspect - for it does not refer to any character of the event, but simply to the proposition's status (Palmer, 2001, 1). For the difference between Zeitstufen and Aktionsarten, see: (Heidegger, 1977a, §68). For grammatical aspect, see: (Comrie, 1976). The consideration of the extent to which Heidegger (from Being and Time to «Time and Being») reduces aspect to a function of time, thereby failing to think being qua aspectual, is beyond the scope of the present discussion.

${ }^{14}$ An onto-chronological consideration of the problem would have to be supplemented with a study of its aspect; or rather, «the study of aspect in general», which I have elsewhere suggested should perhaps rightly take the name of «phenomenology» (Haas, 2015a, 9).
} 
So the other of time is aspect, and the other of being is unity — then if a problem is to be one, a problem, if it comes to presence now and continuously, it does so as an indivisible or divisible one, separate or inseparable from others (Aristotle, 1957, 1052b16). And this is why the history of philosophy as metaphysics is able to determine

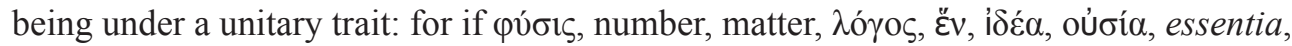
existentia, God, ego, substance, reason, object, concept, spirit, will, power, presence and if any of these are to be the meaning of being, it is because each is one. For unity is how things are - not a unit, nor the unit of all units (like the set of all sets); it is the way in which something is, how it presents itself, appears, comes to presence as indivisible and goes out into absence, is what it is. In this way, unity is how each thing can be unified, united, both in itself and with others. So if we say something like, «the celebration took place in the presence of many guests», we mean «many guests attended one celebration» - for unity means indivisibility, letting each guest be one, separate and together; and every guest can be present at the event that was celebrated because the celebration was one. And unity characterizes how something is, so that it can be what it is, if it is anything at all: whether a plant or animal, stone or human or god, a celebratory event or a non-event, a real Ereignis or even a so-called Enteignis, appropriation or expropriation (Heidegger, 2007, 28), in fact, any word or deed, thought or thing — if it is, it is because it is one. Indeed, unity and being imply one another. For unity is the way in which «everything that is» is, if it is in anyway whatsoever; how things - and things like problems - are real or ideal, in motion or rest, potential or actual, necessary or unnecessary, possible or impossible; how they come to presence or go out into absence. Thus the problem is not simply a question of being, of the being of the problem, or of anything whatsoever; but just as much of its unity and time and aspect, of its way of being one, temporally and aspectually.

\section{THE IMPLICATION OF BEING}

So, being and unity, time and aspect - these would seem essential for any understanding of the problem, even for thinking what is problematic about the problem. But what are they? Or, at least (if we suspend discussion of unity and time and aspect): ${ }^{15}$ what is being - such that it could be the being of a problem? Or, if being is not just the what, but the how of any problem whatsoever, then is it merely presence and/or absence - and tertium non datur, there is no third, kein Drittes. Or is there?

\footnotetext{
${ }^{15}$ In Unity and Aspect (forthcoming), I have attempted to illuminate the problems or implications of being, unity, time and aspect, and how they relate to us, or how they are implicated in and by us (not only in human beings, äv $\theta \rho \omega \pi$ o or ávń $\rho$, nor simply in the being of human beings as Dasein, but just as much by how we are one temporally and aspectually — something which perhaps rightly bears the other ancient name for us, $\varphi \omega ́ \varsigma$, the illuminating one, which is not merely $\varphi \tilde{\omega} \varsigma$, light). See: (Homer, 1922, 21.26); (Homer, 1920, 17.377); (Aeschylus, 1973, 398); (Sophocles, 1990, 107).
} 
For as Aristotle reminds us: being and unity are implied by one another (Aristotle, 1957, 1003b22-24). But what does that mean? To imply? To be implied? To be an implication? Implied by «everything that is», and so by problems?

Another clue from language - for as Benjamin (twenty years before Heidegger) writes: «language alone speaks». ${ }^{16}$ In Greek, Heraclitus says: $\tilde{\hat{n}} \theta$ os áv $\theta \rho \omega ́ \pi \omega ~ \delta \alpha i ́ \mu \omega v$ (Diels, 1960, B119). ${ }^{17}$ McKirahn translates: «a person's character is his divinity» (Diels, 1996, 40; my emphasis); or Kahn: «Man's character is his fate» (Kahn, 1979, 81; my emphasis). Or Heidegger - in typical Heideggerian fashion: «the (familiar) abode for humans is the opening for the presencing of the (un-familiar) god» (Heideger, 1996, 356; my emphasis). But the word «is» is not in the original - for being is not present, which is not to say it is absent; rather, it is implied, an implication. And here, implication is the problem; it is that which fails to present itself, cannot appear, which is not to say that it disappears. But what is implied can be neither necessarily nor even possibly determined as appearing, nor simply asserted to be that which cannot appear; it is that which cannot even be judged to be something or nothing, here or there, now or then, never or always. In this sense, implication is not the opposite or negation of explication, nor can it simply be translated into the language of the explicit, made explicit or explained, at least not without losing precisely that which is being implied. Rather, implication is the problematic suspension of presence and absence, and so suspends the possibility and impossibility, the necessity and contingency, of explication - and so presumably that which makes impression and expression, the coming to presence of explanation, and the historical overcoming of explanation by explanation, so suspenseful. And this is why Heraclitus simply says: human character divine - for «to be» does not mean «to be present», but «to be implied»; being is implying, which is the problem.

Or, in English, «Ode on a Grecian Urn» ends with the following: «When old age shall this generation waste, / Thou shalt remain, in midst of other woe/Than ours, a friend to man, to whom thou sayst, / "Beauty is truth, truth [is] beauty", - that is all / Ye know on earth, and all ye need to know». ${ }^{18}$ In other words, «is» is not present, and not just absent either - for being is implied. And being's way of being is what the poem is about; it is the secret of the poem, if not of $\pi$ oínбıs itself, a secret kept hidden in full-view, suspended before our eyes, neither visible nor invisible, neither there nor not-

\footnotetext{
${ }^{16}$ (Benjamin, 1991, II.1, 144); (Heidegger, 1985b, 243); (Haas, 2014). Or as Hegel writes: «The formsof-thought are first set-out and put-down in human language» (Hegel, 1974, 20).

${ }^{17}$ Also see, for example: (Plato, 1922, Laws, X, 901c8-d2); (Kahn, 2003, XIIn11).

${ }^{18}$ (Keats, 1814-1891, 3.2, my emphasis). T. S. Elliot's assessment is clear: «this line strikes me as a serious blemish on a beautiful poem; and the reason must be either that I fail to understand it, or that it is a statement which is untrue» (Brooks, 1949, 140). Being is not simply implied for poetic reasons: Keats does not exclude it because he needs ten syllables for the line to scan-there are multiple ways in which the poem could have been constructed in iambic pentameter. In other words, being is not implied so it fits the poem; rather, if it fits the poem, it is because being is implied.
} 
there, neither happening nor not-happening. So that being qua implication is the «still unravish'd bride of quietness», which haunts the poem; it is the meaning that - failing to present itself - cannot be grasped, understood, known. Thus, like the poem's «Bold Lover», who cannot kiss the beloved, so too that being which is implied cannot come to presence and present itself, cannot be asserted or apodeicted, revealed or concealed, demonstrated or determined; although nor can it remain absent and in absence - for it is merely an implication.

Or, in Russian present tense, the first line of Notes from Underground reads: «Я человек больной... Я злой человек» (Dostoevsky, 1864). But Pevear and Volokhonsky translate: «I am a sick man... I am a wicked man» (Dostoyevsky, 1993, 1). Again, the translation is not «wrong», it is «right». But the text says: «I man sick», or - as Russian word order (like Greek) is flexible — «I sick man...I wicked man». And there is no «is»; being is not there; it is not present and does not come to presence, although nor is it absent; it is not necessary to write being between subject and predicate, nor is it actually even possible, without doing a certain kind of injustice - if not violence - to implication, to being, to the being (and unity and time and aspect) of being, so to thinking and speaking, doing and imagining and feeling, to «everything that is» — for being is, as every Russian speaker knows, only implied, an implication.

Language then, tells us that being is implied; it tells us what being is - namely, an implication. But what is that? Or more precisely: what does it mean to think how being is implied? For how can implication be thought as being? And so, as the being of something like a problem?

In fact, if an implication is neither present nor absent, but just implied - it is because implication is a problem. ${ }^{19}$ Then implied being — not only in speaking, but just as much in doing and thinking, or more precisely, in «everything that is» - is problematic. For implication is a way of being that suspends the necessity and contingency, the possibility and impossibility, of being there, of the event of coming to presence - indeed, of presence itself, and absence. So that which is problematic about the problem is that being (and unity, time, aspect) is only implied. Then being's way of being is in suspense, neither something nor nothing, neither being nor non-being. For being is an implication - and so, tertium dator, a third thing, a problem to be held, kept, carried, borne. And if being can be asserted as a possibility, or apodeicted as a necessity, it is because being qua implication is first problematic. Thus the problem of being, that which is problematic about being, is the problem of implication, or how being is implied.

\footnotetext{
${ }^{19}$ For Grice, «echoing Kant», the Critique's «Table of Judgments» means that implication is either necessary or possible, and tertium non dator (Grice, 1989, 26, 30, 38, 189); see also: (Kant, 1900, IV: A75/III: B100); (McColl, 1877, 10); (Frege, 1879, §5); (Whitehead \& Russell, 1907, 20-21). In other words, Grice's loyalty to Kant prevents him from thinking problematic implication. For being qua implication, see: (Haas, 2007a, 208-210).
} 
And not just being - for insofar as a problem is and is one, temporally and aspectually, it is, and so is problematic. But if we seek to take it up as a problem, keep it in suspension (like the problem of perfect justice, perhaps of any justice whatsoever), and so attempt to think that which does not come to presence, nor remains in absence, thereby to problematize the problem; then it seems we must also admit that none of this is necessary, nor actually even possible - for we cannot know what a problem is, or even that it is, that there is a problem; nor can we say that it is something or nothing at all. Rather, insofar as the problem is thinking the problematic, what the problem is, how it is implied; the problem would be to think the suspension of the problem - if we can bear it, and if it is to be problematic, whatever the implications - and so to think how the problem suspends thinking. For as Parmenides reminds us: it is not just a matter

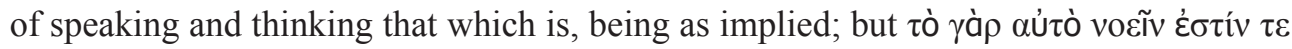

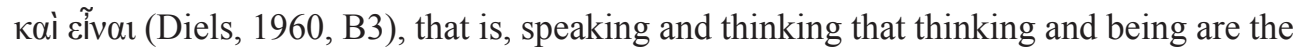
same, namely, problematic.

\section{REFERENCES}

Aeschylus (1973). Septem Quae Supersunt Tragoedias. Oxford: Clarendon Press.

Aristotle (1950). Physica. Oxford: Oxford University Press.

Aristotle (1957). Metaphysica. Oxford: Oxford University Press.

Benjamin, W. (1991). Gesammelte Schriften. Frankfurt: Suhrkamp.

Brooks, C. (1949). The Well Wrought Urn. London: Dobson Books.

Comrie, B. (1976). Aspect. Cambridge: Cambridge University Press.

Derrida, J. (1967). La voix et le phénomène. Paris: PUF.

Derrida, J. (1972). Ousia et grammè: note sur une note de Sein und Zeit. In Marges de la philosophie. Paris: Minuit.

Derrida, J. (2001). L’Université sans condition. Paris: Galilée.

Derrida, J. (2003). Voyous. Paris: Galilée.

Diels, H. (1960). Die Fragmente der Vorsokratiker. Hildesheim: Weidmann.

Dostoyevsky, F. M. (1864). Zapiski iz podpol'ya [Notes from Underground]. St. Petersburg: Epokha. (in Russian).

Dostoyevsky, F. M. (1993). Notes from Underground. New York: Alfred A. Knopf.

Frege, G. (1879). Begriffschrift. Halle: Louis Nebert.

Grice, P. (1989). Studies in the Way of Words. Cambridge: Harvard University Press.

Haas, A. (2007a). Being and Implication: On Hegel and the Greeks. Cosmos and History: The Journal of Natural and Social Philosophy, 3 (3), 192-210. 
Haas, A. (2007b). The Irony of Heidegger. London: Continuum International Publishing.

Haas, A. (2014). Notes on Benjamin and Intimacy. Rivista Italiana di Filosofia del Linguaggio, $8(2), 112-124$.

Haas, A. (2015a). Notes on Time and Aspect. International Journal of Philosophical Studies, 23 (4), 504-517. doi: 10.1080/09672559.2014.996245.

Haas, A. (2015b). The Ambiguity of Being. In Georgakis, T., \& Ennis, P. J. (Eds.), Heidegger in the Twenty-First Century (9-22). Dordrecht: Springer. doi: 10.1007/978-94-017-9679-8_2.

Hegel, G.W.F. (1974). Wissenschaft der Logik I (Bd. V). Frankfurt: Suhrkamp.

Hegel, G.W.F. (1970). Grundlinien der Philosophie des Rechts. Mit Hegels eigenhändigen Notizen und den mündlichen Zusätzen (Bd. VII). Frankfurt: Suhrkamp.

Heidegger, M. (1975). Die Grundprobleme der Phänomenologie (GA 24). Frankfurt a. M.: V. Klostermann.

Heidegger, M. (1976). Logik. Die Frage nach der Wahrheit (GA 21). Frankfurt a. M: V. Klostermann.

Heidegger, M. (1977a). Sein und Zeit (GA 2). Frankfurt a. M: V. Klostermann.

Heidegger, M. (1977b). Phänomenologische Interpretation von Kants Kritik der reinen Vernunft (GA 25). Frankfurt a. M.: V. Klostermann.

Heidegger, M. (1979). Prolegomena zur Geschichte des Zeitbegriffs (GA 20). Frankfurt a. M: V. Klostermann.

Heidegger, M. (1983). Einführung in die Metaphysik (GA 40). Frankfurt a. M: V. Klostermann.

Heidegger, M. (1984). Die Frage nach dem Ding. Zu Kants Lehre von den transzendentalen Grundsätzen (GA 41). Frankfurt a. M: V. Klostermann.

Heidegger, M. (1985a). Phänomenologische Interpretationen zu Aristoteles. Einführung in die phänomenologische Forschung (GA 61). Frankfurt a. M: V. Klostermann.

Heidegger, M. (1985b). Unterwegs zur Sprache (GA 12). Frankfurt a. M: V. Klostermann.

Heidegger, M. (1989). Beiträge zur Philosophie (Vom Ereignis) (GA 65). Frankfurt a. M: V. Klostermann.

Heidegger, M. (1991). Kant und das Problem der Metaphysik (GA 3). Frankfurt a. M.: V. Klostermann.

Heidegger, M. (1993). Hegel (GA 68). Frankfurt a. M: V. Klostermann.

Heidegger, M. (1996). Wegmarken (GA 9). Frankfurt a. M: V. Klostermann.

Heidegger, M. (2002). Grundbegriffe der aristotelischen Philosophie (GA 18). Frankfurt a. M: V. Klostermann.

Heidegger, M. (2004). Der Begriff der Zeit (GA 64). Frankfurt a. M: V. Klostermann.

Heidegger, M. (2007). Zur Sache des Denkens (GA 14). Frankfurt a. M: V. Klostermann. 
Homer (1920). Homera Operi: Illiad (Vol. II). Oxford: Clarendon Press.

Homer (1922). Homera Operi: The Odyssey (Vol. IV). Oxford: Clarendon Press.

Husserl, E. (1977). Ideen zu einer reinen Phänomenologie (Hua III/1). Den Haag: Nijhoff.

Husserl, E. (1973). Cartesianische Meditationen (Hua I). Den Haag: Nijhoff.

Kahn, C. (1979). The Art and Thought of Heraclitus. Cambridge: Cambridge University Press.

Kahn, C. (2003). The Verb «Be» in Ancient Greek. Indianapolis: Hackett.

Kant, I. (1900). Gesammelte Schriften. Berlin: Akademie der Wissenschaften.

Keats, J. (1814-1891). Transcripts of Unpublished Poems, common place book of R. Woodhouse. Boston: Houghton Library, Harvard University.

McColl, H. (1877). The Calculus of Equivalent Statements and Integration Limits. Proceedings of the London Mathematical Society, 9, 9-20.

Nietzsche, F. (1967). Also Sprach Zarathustra. Berlin: de Gruyter.

Palmer, F. (2001). Mood and Modality. Cambridge: Cambridge University Press.

Plato (1922). Platonis Opera. Oxford: Oxford University Press.

Schmitt, C. (2006). Hamlet or Hecuba. Corvallis: Plutarch Press.

Sophocles (1990). Fabulae. Oxford: Clarendon Press.

Whitehead, A. N., \& Russell, B. (1907). Principia Mathematica. Cambridge: Cambridge University Press.

Wittgenstein, L. (1921). Logisch-Philosophische Abhandlung. In W. Ostwald (Ed.), Annalen der Naturphilosophie (185-262). Leipzig: Unesma. 